\title{
Corporate Governance Practices and Firm's Capital Structure Decisions: An Empirical Evidence of An Emerging Economy
}

\author{
Hassan M. Hafez ${ }^{1}$ \\ ${ }^{1}$ Business Administration Department, Canadian International College ("CIC"), Cairo, Egypt \\ Correspondence: Hassan M. Hafez, Business Administration Department, Canadian International College (“CIC”), \\ Cairo, Egypt
}

Received: August 24, 2017

Accepted: September 13, 2017

Online Published: September 14, 2017

doi:10.5430/afr.v6n4p115

URL: https://doi.org/10.5430/afr.v6n4p115

\begin{abstract}
There is a growing body of literature that recognises the importance of corporate governance practices on capital structure decisions. However, results are not consistent and only a few studies have been able to draw on any systematic research trying to quantify the relation between corporate governance practices and capital structure decisions and to acquire bits of knowledge of such relation of listed firms in Emerging Economies. Because of the fact that impact use of the corporate governance rules can have on capital structure decisions.

The main driver of this research is to investigate the sound use of the Egyptian corporate governance practices on capital structure decisions of listed firms in Egypt over the period 2007 to 2016 utilizing a sample of 50 listed firms in EGX 100. Empirical results demonstrate the significant relationship between various inner and outer corporate governance practices and capital structure decisions of listed firms in Egypt. The findings were quantitatively approved through utilizing E-Views programming for examining panel data. Descriptive statistics, Multi-Collinearity test, Hausman test and multiple regression have been utilized to distinguish the major determinates of capital structure decisions and assess whether it has a significant impact on capital structure decisions.
\end{abstract}

Keywords: Corporate governance, Capital structure, Emerging economy

\section{Introduction}

A standout amongst the most noticeable money related outrages, Enron provoked by abuse and botch that bring about costing shareholders billions of dollars and furthermore disturbed organizations' financial position manageability. Consequently, from shareholder point of view, the development of venture rivalry and activism began to be existed as they need to have the capacity to think about and look at organizations' performance. in view of rudiments norms of full disclosure and transparency in financial position before taking investment decisions (Choudhury. T, Mukherjee, K. and Singh, V., 2001). From management point of view, management should be worried to run business in a transparent and credible way before raising any finance, in order to ensure decreasing the conceivable outcomes of corruption with a specific end goal to guarantee flourishing and economy development. Because of the imperfection of developing market mechanism, corporate governance can act a fundamental player in functioning financial market regarding impartial allotment of financial resources.

Thusly, it has turned out to be crucial for any organization to actualize sound productive corporate governance practices that will consequently affect organizations' image in the market. Numerous specialists discussed that each firm may has an optimal leverage ratio. Each firm is motivating force attempting to adjust to optimal debt-equity ratio. But, this strategy has a principal obstacle which is taking a period of time particularly when firms confront adjustments costs.

(Myers, 1984) stated that firms that have a large adjustments cost take prolonged outings away from their target debt equity ratio therefore, recognizing the adjustment cost is a main concern. Accordingly, there is real impact of corporate governance quality on the speed of capital structure adjustments. Therefore, corporate governance practices can be viewed as a way to identify the optimal debt equity ratio in order to maximize the value of the firm (Pratheepkanth, 2011). Early research by Miller and Modigliani, (1958) is the primary research to look at the relevance of capital structure decisions in an efficient capital market. Not only that but also to investigate the determinants of capital structure decisions (Al-Najjar, B. and Hussainey, K., 2011b). The substance of executing corporate governance practices is significant for the growth of any company and the development to any economy. A 
well prepared corporate governance practices concentrate on how firms managed internally and observed by board of directors in order to secure the shareholders wealth who can see whether their benefits are served and to ensure making a rational investment decisions. La porta et al, (1997) assure that corporate governance frameworks in a few countries are the same, for instance, Asia, European countries and Anglo America while in MENA region, there are diverse monetary issues resulted in different corporate governance frameworks basically because of the legal frameworks and state ownership of firms that lead to the difficulty to execute an efficient corporate governance practices.

Berger et al. (1997) claimed that managers utilize more debt even beyond the optimal debt equity level keeping in mind the end goal to secure themselves against takeovers. Self-interested managers used to build their own advantages in this way they used to extend debt obligations notwithstanding its effect on shareholders wealth. The utilization of debt obligations limit self-interest managers flexibility to utilize free cash flows (Jensen, 1986). Corporate governance is a set of standards and rules that oversee and control managers decisions inside the firm to overcome any conflicts arise between principal and agent. It decrease signally information costs (Rocca, 2007).

\section{The Contribution of the Research}

The main contribution of this research is to present a full picture of the impact to implementing an efficient corporate governance practices which in turn force capital structure decisions to be efficient. This research tries to fill the gap in the literature review by lighting up the real association between corporate governance practices and capital structure decisions of listed firms in Egypt. Information asymmetry is still a main concern in the developing countries besides, capital market in Egypt is undeveloped since Egyptian firms still rely on equity rather the than bond market. As a result, this sort of economic market conditions besides the rise of business failure could essentially make the financing decisions to be irregular and increase the need to prepare and execute a good and efficient corporate governance practices.

\section{Literature Review}

\subsection{Capital Structure}

The trade-off theory developed by Miller and Modigliani (1958) stating the insignificance of the capital structure on overall firm performance. As long as we increase the debt proportion in the capital structure this in turn will decrease the cost of capital since we deduct the interest expenses before paying taxes. Miller and Modigliani (1963) added that the change in capital structure does not influence firm value when considering taxes and transaction costs. The higher the proportion of debt in the capital structure the higher the cost of equity as shareholders will bear higher corporate risk represented in the bankruptcy risk. Their model paved the way to a various number of theories. The agency theory as an economic theory is defined as an agreement that the agent performs a few administrations for the chief sake by assigning the agent to make decisions Alchain and Demstez (1972); Jensen and Meckling (1976). The agency cost is about controlling and observing the expenses to ensure the increase of benefits to shareholders. In this manner, Jensen asserts that debt financing is used in order to decrease the agency costs between principal and agent.

Ross (1977) developed the signaling theory which is connected to the symmetric information that is transferred as signal to potential investors in the market. When managers owns information about the future of the firm's return which is not known by shareholders, in that case the signal information expenses will exist (Mjluf, N., and Myers, S.C., 1984). Firms should not to convey any misleading information to potential investors in the market as investors can recognize among firms using such signals. For instance, the issuance of debt can be a very expressing signal to convey to the market guaranteeing that the firm will have the capacity to pay its debt obligations in due date. Thus, potential investors certainty will increase their stake in the firm (Chang, R.P. and Rhee, S.G., 1990).

In 1984, Myers developed the pecking order theory which contend that corporate governance is more important to determine the performance of the firm. It related to inside information asymmetry and the conflict of the adverse selection related to capital structure decisions. Firms would prefer the internal finance rather than external finance so that to save the transactions costs. Subsequently, managers should to be urged to concentrate on expanding the interest of shareholder rather than expanding the level of debts. Subsequently, the capital structure influences the firm performance.

\subsection{Corporate Governance}

The ultimate goal of corporate governance is to limit asymmetric information to occur and to making firms exist in the business for a long time. (Azeem, M., Hassan, M., and Javeed,A., 2014). Moreover, the debt financing strategy is a key of a good corporate governance practices by adjusting the agency problems through reducing the free cash flows and the bankruptcy risk (Jensen, M. and Meckling, W., 1976). 
Jensen (1986) claimed that debt finance can be obstacle toward managers' adaptability. Self-interest managers don't concentrate on settling capital structure decisions that expand shareholders' wealth. Therefore, firm's leverage should be influenced by both firm specific indicators and corporate governance practices. Many reviews assured that a well prepared corporate governance practices such as the size of the board of directors, the number of institutional investors, the quality of external auditors, the concentration of the ownership and chief financial officer compensation have an influence on Capital structure decisions.

\subsection{Corporate Governance Practices and Capital Structure Decisions}

Corporate governance has a different points of interest for the developing countries such as Egypt. It incorporates many arrangements as it grantees transparency and corporate disclosure that submitted by Egyptian Corporate Governance Code ("ECGC") in 2005. Besides, Egyptian firms are late in the implementing of Corporate Governance practices.

Sheik and Wang, (2012) examined the effect of corporate governance characteristics including the size of the board of directors, the external director and chief financial officer duality on capital structure decisions of 436 listed firms in Karachi stock exchange over the period 2004 to 2008. The study used total and long term debt finance as a proxy of capital structure decisions. Empirical evidence showed that there is a positive relationship between the size of the board of directors, the external director and capital structure variables, demonstrating that independent directors support the concept to use more debt to pursue more control on the firm. However, there is a negative relationship between the managerial ownership and total debt finance ratio demonstrating that the interest of a firm managers is align with the external shareholders consequently decreasing the debt financing to decrease the agency problems. Chief financial officer duality has a statistically insignificant relationship with the total debt ratio.

Aljifri and Hussein (2012), examined the relationship between the internal and external corporate governance practices and capital structure decisions of 71 listed firms in UAE in 2006. They found that there is a significant negative relationship between the institutional investors and the debt to equity ratio, demonstrating that the larger segment of shares owned by the institutional investors the lower the use of debt financing and this is consistent with the pecking order hypothesis. Also they found that there is a significant relationship between the size of the board of directors, the governmental investors, the external auditor and capital structure decisions.

Other capital structure theories: Agency, Trade-off and transaction cost theory have no significant relationship with corporate governance practices. Due to the various culture and institutional components form the relationship between corporate governance and capital structure in UAE. UAE do not impose taxes on business firms, therefore there is no relationship between tax shield and the use of debt in capital structure reflecting the incompatibility with trade off theory.

Ya-kai, chang., Robin K. Chou., (2014). Examined the effect of corporate governance on optimal capital structure choices. They dmonstrated that coporate governance has a distict effect on the speed of capital structure adjustment. Both underlevered and overlevered firms with weak governance adjust slowly toward the optimal capital structure. These reults supported also by Li-Kai, Loai., Taurn, Mukherjee., and Wei, Wang., (2015) since they demonstrated that the higher level of financial leverage and a faster speed of adjustment toward the shareholders' desired level of capital structure are always associated with better corporate governance quality.

Granado, P., Noelia.; Lopez, G., and Jose. (2017), investigated the relationship between corporate governance and capital structure. They used a panel data of Spanish listed firms over the period 2005 to 2011 and focused on two major variables; the managerial ownership and the controlling shareholders ownership. Results demonstrated that there is a non-monotonic relationship between both variables and capital structure. They also confirms that shareholders' need to monitor managers performance in order to prevent the expropriation of minority shareholders and the desirability of examining corporate governance variables to better understand the firm financial policy. On the other side, Vogt., Mara; Simao K., Itzhak D., Degenhart., and Larissa; (2017), investigated the attributes of Corporate Governance affect the capital structure of 41 Brazilian companies belonging to the BM \& FBOVESPA consumption over the period 2010 to 2013. Results demonstarted that some mechanisms of Corporate Governance do not have significant influences on capital structure. The shareholding and remuneration of directors are variables that have a significant impact on capital structure decisions. This means that corporate governance, in part, explain the business financing behavior of Brazilian companies. Extending to those reuslts, Vivek, Mande,Young, K. Park., and Mynugsoo, Son., (2012) proved that corporate governance effecitiveness have a positive impact on chossing equity to debt finance using a sample of over 2,000 US equity and debt issunances over the period 1998 to 2006. 
The number of board of directors is the most fundamental corporate governance practices since it is the main factor responsible for observing the strategic decisions of the firm's. Empirical results on the relationship between the size of the board of directors and capital structure decisions are not consistent. Kochhar, (1986) and Jensen (1996) assure that there is a positive relationship between the size of the board of directors and capital structure in order to decrease the agency costs; firms with the larger board of directors probably use more debt financing in its capital structure rather than equity due to the entrenched regulatory authorities. On the contrary, Merhan (1992) emphasized that there is a negative relationship between the board of directors and the debt to equity finance taking into consideration the end goal to improve the firm's financial performance. Accordingly we can develop the following hypothesis as follows:

Hypothesis 1: There is a positive relationship between the size of the board of directors and the leverage ratio.

The institutional investors can screen the decisions of the managers toward the shareholders' benefits reflecting to decrease the agency costs. Also because of the reality of having facilitated access to different information access compared to other investors (Lev, 1988). Crutchely et al, 1999, affirms that there is a positive relationship between the institutional investors and the leverage ratio. Therefore, we can develop the following hypothesis as follows:

Hypothesis 2: There is a positive relationship between the institutional investors and the leverage ratio.

The government ownership in a firm could be viewed as one of the corporate governance practices. Gahzali and Weetman, (2006) certify that the governmental ownership is more contributed to observing and can act as a disclosure substitution. We can develop the following hypothesis as follows:

Hypothesis 3: There is a positive relationship between the governmental ownership and the leverage ratio.

Another angel of the corporate governance practices is the quality of the external auditor as it is used as index for assessing the information asymmetry inside the firm. According to Bharath et al. (2009) there is a positive relationship between the new information asymmetry index and the leverage ratio. However, Hussainey (2009) contends that it is a negative relationship showing that the level of information asymmetry decreases accordingly the investor has a positive future expectations toward the stock earning as the financial statements will be locked in with one of the big four auditing firms in UAE. The big four widely auditing firms known in Egypt are Central Auditing organization, Ernest and Young, Deloitte and KPMG. Thusly, we can develop the following hypothesis as follows:

Hypothesis 4: There is negative relationship between the efficiency of the external auditor and the leverage ratio.

The concentration of the ownership is one of determinants of corporate governance practices. Egyptian listed firms are less duality in position and high the ownership concentration which could be viewed as Block holder ownership. Accordingly we can develop the following hypothesis as follows:

Hypothesis 5: There is a positive relationship between the concentration of the ownership and the leverage ratio.

Early studies examined the relationship between firm specific indicators as a control variables, for instance, the profitability, the size of the firm, the dividend payout ratio and capital structure decisions. Myers (1999) claimed that the growth of the firm measured by the profitability ratio is negatively correlated to the debt to equity ratio which in turn consistent with the tradeoff theory. In spite, Kayhan and Titman (2007) contend it is negatively correlated to the debt to equity ratio that supporting the pecking order theory.

According to Al Najjar and Hussainey (2011 a,b), there is a positive relationship between the size of the firm and the debt to equity ratio since large firms attempting to decrease the cost of debt by capitalizing the economies of large scale.

Jensen et al. (1992), stated that the dividend payout ratio is negatively correlated with the debt to equity ratio. Notwithstanding, Change and Rhee (1990) claimed that it is a positive relationship as the firm with the higher dividend payout ratio is probably have a high leverage ratio consequently will have the capacity to pay off its future commitment as scheduled. Salim and Yadav (2012) certified that capital structure decisions influence the performance of the firm whereas Tobin's $Q$ is significantly negatively correlated with the capital structure decisions.

\section{Research Design and Methodology}

\subsection{Research Aim}

The absence of broad review which by and large look at whether the internal and external corporate governance practices influence capital structure decisions of Egyptian listed firms. the past reviews were basically limited to either developed economies or large developing economies. Emanating from the essential role of implementing an effective corporate governance practices specifically in emerging economies. 


\subsection{Data}

Data extracted on listed firms in EGX 100 covering almost all industries with the exception of banking and financial institutions because of the diverse corporate governance practices applied. Since corporate governance framework applied on companies varies than corporate governance applied on banks due to the difference in regulatory bodies and frameworks are used. Sample represent approximately 67\% of EGX100 population. Data of the selected listed firms was compiled from the annual Financial statements, corporate governance information disclosure book included in the annual report loaded on the Egyptian exchange website, and each company website over the period 2007 to 2016.

Table 1. companies distributed cross industries

\begin{tabular}{|c|c|}
\hline Industry $\quad$ Number of Companies Related to & each Industry \\
\hline Real Estate & 9 \\
\hline Chemicals & 3 \\
\hline Personal and House holds & 8 \\
\hline Food and Beverages & 5 \\
\hline Health and Pharmaceuticals & 4 \\
\hline Constructions and Materials & 6 \\
\hline Media & 1 \\
\hline Industrial Goods and Services and Automobiles & 3 \\
\hline Oil and Gas & 1 \\
\hline Retails & 1 \\
\hline Utilities & 1 \\
\hline Basic Resources & 1 \\
\hline Technology & 1 \\
\hline Travel and Leisure & 3 \\
\hline Telecommunication & 3 \\
\hline Total & 50 \\
\hline
\end{tabular}

Source: Egyptian Financial Supervisory Authority. 


\subsection{Variable Definition:}

Table 2. Variables definition

\begin{tabular}{ll}
\hline Variable Name & Definition \\
\hline Capital Structure Decisions & Dependent Variable \\
& \\
Short Term Debt Finance & Short term debt finance/ total equity \\
Long Term Debt Finance & Long term debt finance/ total Equity \\
Total Debt Finance & Total debt finance / total assets \\
\hline Corporate Governance Practices & Independent Variables
\end{tabular}

The Board Size

The Institutional Investors

The Governmental Ownership

The External Auditor

The Ownership Concentration
The number of directors at the board at the reporting date

The proportion of ordinary shares owned by institutional investors

The proportion of ordinary held by the government

A variable is measured through symbol either 1 for the companies that is audited by one of the four large auditing firms as existed in the Egyptian Corporate Governance index figure 1. In the appendix.

The ratio of shares held by the big five shareholders to total shares

Controllable Variables

The Firm Size

The Dividends Policy

The Profitability
The natural logarithms of total assets

The Dividend pay-out ratio

Net Profit after tax to total assets

Panel data will be examined utilizing E-views software. Descriptive statistics were constructed. Ordinary Least square (NLS and ARMA) multiple regression for each dependent variable was used to test for the resulting main explanatory model after conducting Multi-Collinearity. Furthermore, we used the Hausman test in order to evaluate the fixed and variable effect of panel data. Accordingly, ordinary least square multiple regression will be utilized to analyse the effect of corporate governance practices on each of the three selected dependent variables which are STDF, LTDF and TDF along with control variables. We can examine the developed hypotheses through the below models as follows:

$$
\begin{aligned}
& \mathrm{STDF}=\beta 0+\beta 1 \mathrm{INSit}+\beta 2 \mathrm{BSIZEit}+\beta 3 \mathrm{EXTAUit}+\beta 4 \mathrm{GOit}+\beta 5 \mathrm{OWNit}+\beta 6 \mathrm{PROit}+\beta 7 \mathrm{FSIZit}+\beta 8 \mathrm{DIVit}+\dot{\varepsilon} . \\
& \mathrm{LTDF}=\beta 0+\beta 1 \mathrm{INSit}+\beta 2 \mathrm{BSIZEit}+\beta 3 \mathrm{EXTAUit}+\beta 4 \mathrm{GOit}+\beta 5 \mathrm{OWNit}+\beta 6 \mathrm{PROit}+\beta 7 \mathrm{FSIZit}+\beta 8 \mathrm{DIVit}+\dot{\varepsilon} . \\
& \mathrm{TDF}=\beta 0+\beta 1 \mathrm{INSit}+\beta 2 \mathrm{BSIZEit}+\beta 3 \mathrm{EXTAUit}+\beta 4 \mathrm{GOit}+\beta 5 \mathrm{OWNit}+\beta 6 \mathrm{PROit}+\beta 7 \mathrm{FSIZit}+\beta 8 \mathrm{DIVit}+\dot{\varepsilon} .
\end{aligned}
$$

STDF is the short term debt finance, LTDF is the long term debt finance and TDF is to total debt Finance which represent capital structure decisions (dependent variables).

The independent variables are; INS is the institutional investors, BSIZE is the size of the board of directors, EXTAU is the external auditor, GO is the governmental ownership and OWN is the concentration of the ownership. In terms of the control variables, PRO is the profitability ratio, FSIZ is the size of the firm and DIV is the dividend payout ratio. $\alpha$ is the intercept. $\beta$ is the slope coefficient. $\dot{\varepsilon}$ error term and firm is represented by $i$ and $t$ represent time horizon.

\subsection{The Assumptions of the Model}

We used normality test to measure the residuals of the model. We solved the issue of the absence of outliers through lagged continues variables. Hausman test is used to examine fixed or random effect meaning that null hypothesis which is random effect is efficient and consistent however alternative hypothesis which is random effect is 
inefficient and inconsistent. This test enable us to assess the size effect to forecast mean effect of the distribution by using a wide range of data whether they are fixed or random.

Table 3. Descriptive statistics

\begin{tabular}{llllllllllll}
\hline & STDF & LTDF & TDF & OWN & GO & INS & EXTAU & BSIZE & FSIZ & PRO & DIV \\
\hline Mean & 0.501 & 0.157 & 0.657 & 0.308 & 0.685 & 0.757 & 0.736 & 10.428 & 7.70 & 1.85 & 0.90 \\
Median & 0.624 & 0.053 & 0.695 & 0.034 & 0.139 & 0.17230 & 1.00 & 10.00 & 9.23 & 0.13 & 0.21 \\
Maximum & 0.803 & 0.85 & 1.654 & 36.256 & 73.162 & 49.900 & 1.00 & 25.00 & 10.85 & 47.7 & 295.0 \\
Minimum & 0.00 & 0.000 & 0.00 & 0.00 & 0.000 & 0.000 & 0.00 & 4.00 & 3.76 & -39.7 & 0.05 \\
Std. Dev. & 0.152 & 0.1694 & 0.236 & 2.075 & 5.3114 & 4.7466 & 0.418 & 4.173 & 1.81 & 5.98 & 13.31 \\
Skew. & -0.800 & 1.6019 & -0.124 & 14.250 & 12.6784 & 9.85358 & -1.324 & 0.807 & -.59 & 2.44 & 21.69 \\
Probability & 0.00 & 0.000 & 0.00 & 0.00 & 0.00 & 0.00 & 0.00 & 0.00 & 0.00 & 0.00 & 0.00 \\
Sum & 206.7 & 68.5286 & 315.2 & 143.789 & 357.66 & 373.437 & 388.00 & 5214.0 & 3752. & 875.7 & 460.8 \\
Observation & 500 & 500 & 500 & 500 & 500 & 500 & 500 & 500 & 500 & 500 & 500 \\
\hline
\end{tabular}

Table 3 illustrates the descriptive statistics of the research variables. The observed calculated descriptive statistics consists of mean, median, minimum, maximum, standard deviation, and skewness. All of the variables are asymmetrical. Especially skewness is positive for long term debt finance, the ownership concentration, the institutional investors, the governmental ownership, the size of the board, the net profit and the payout ratio meaning that distribution symmetrically to long tail to right. While total debt finance, short term debt finance, both the external auditor and the size of the firm have a negative skewness supporting that symmetric distribution has a long tail to the left.

Egyptian listed firms rely more on short term debt finance through accessing banks. Not only that but also in essence the long term debt finance is the only instrument available due to the lack of developed public debt market. Total assets are basically financed by short and long term debt finance. Therefore, Egyptian listed firms have a high level of leverage ratio.

The increase in the concentration of the ownership in a poor corporate governance practices will enable shareholders to authorize informational advantage by preferably choosing the right debt instrument to meet the firms' financing requirements which in turn resulted in the inconsistency with the pecking order hypothesis.

The Governmental investors holding shares less than the institutional investors is supported by ( Hussainey,K. and Aljifri,k., 2012). In addition, The mean (median) of the external auditor is $73.6 \%$ (1.00) meaning that listed firms are audited by one of the big four auditing firms in Egypt. The mean (median) of the size of the board of directors is 10.4 (10) indicating that an average number of listed firms have at least 10 members in the board of directors which also supported by (Dahawy, K.; Hussainey, K. Samaha, K.; and Stapleton, P., 2012).

Most of the selected firms are generating profit which supported by ( Aljifri,k. and Hussainey,K., 2012). Furthermore, the mean (median) of the pay-out ratio is $90 \%(21 \%)$ indicating that the higher the payout ratio the higher the likelihood to increase the debt financing because of the decrease in retained earnings (Chang, R.P. and Rhee, S.G., 1990).

\subsection{Correlation Analysis}

As it is shown in table 3 we can conclude that there is no multi-Collinearity among the research variables .

The concentration of the ownership has an insignificant negatively correlated with LTDF and TDF. The higher the proportion of firm shares held by a major shareholders the lower the use of debt financing as supported by Stapleton el at. (2012). On the other hand, the relationship of the concentration of the ownership is weak positively correlated but not significant with short term debt finance.

The Institutional investor has a significant weakly negatively correlated with both STDF and TDF. Egyptian listed firms with the higher proportion of the institutional investors are the lower use of debt financing. This finding supported also by ( Aljifri,k. and Hussainey,K., 2012) and is reverse to the findings of (Shleifer, A. and Vishny, R., 1986). On the contrary, the institutional investor is insignificant weakly positively correlated with long term debt finance. 
The Governmental ownership has a insignificant positively correlated with both STDF and TDF. The higher proportion of the shares held by the governmental ownership the higher to use short term debt finance. On the contrary, the governmental ownership is insignificant negatively correlated with long term debt finance.

The size of the board of directors has a significant weak positive correlation with both STDF and TDF. This means that the increase in the size of the board of directors will increase the debt financing and in its turn will lead to agency conflicts between managers and shareholders. however, there is an insignificant weak negative correlation with LTDF and these findings are agreed by (Aljifri,k. and Hussainey,K., 2012).

The External Auditor has a significant weak positively correlated with both STDF and TDF. Whereas insignificant weak positive correlation with LTDF.

The size of the firm is weakly positively correlated with both STDF and TDF. This is consistent to the findings of ( Aljifri,k. and Hussainey,K., 2012). But the size of the firm has a significant weak negative correlation with LTDF.

The net profit and the payout ratio have an insignificant weak negative correlation with all dependent variables (LTDF,STDF and TDF). These findings are supported by (Aljifri,k. and Hussainey,K., 2012) and (Klapper, L. and Love, I., 2004).

4.5 Regression Analysis:

4.5.1 In terms of Short Term Debt Finance

$\mathrm{STDF}=\beta 0+\beta 1 \mathrm{INSit}+\beta 2 \mathrm{BSIZEit}+\beta 3$ EXTAUit $+\beta 4 \mathrm{GOit}+\beta 5$ OWNit $+\beta 6$ PROit $+\beta 7 \mathrm{FSIZit}+\beta 8$ DIVit $+\dot{\varepsilon}$.

Table 4. Panel Data Regression Model

\begin{tabular}{llll}
\hline Description & $\begin{array}{l}\text { Expected significant } \\
\text { based on hypothesis }\end{array}$ & Coefficient $\beta$ & (P-value) \\
\hline Constant & -ve & 0.067 & Significant \\
Board Size & $+\mathrm{ve}$ & $3.126 \mathrm{E}-04$ & Not Significant \\
Institutional Investor & $+\mathrm{ve}$ & -0.00167 & Significant \\
Govern. Ownership & $+\mathrm{ve}$ & 0.00065 & Not significant \\
External Auditor & $+\mathrm{ve}$ & 0.03748 & Significant \\
Dummy variables & & & \\
Ownership concentration & $+\mathrm{ve}$ & 0.000572 & Not Significant \\
Net Profit & $-\mathrm{ve}$ & 0.001219 & Not Significant \\
Firm Size & $+\mathrm{ve}$ & 0.005162 & Not Significant \\
Dividend pay-out & $-\mathrm{ve}$ & -0.00541 & Not Significant \\
$\mathrm{R}^{2}$ & Adjusted $\mathrm{R}^{2}$ & F-Test & SE $*$ D. W \\
$56.2 \%$ & & Significant $56 \%$ & $0.114 \quad 2.12$ \\
& $55 \%$ & p-value $<0.05$ &
\end{tabular}

\section{* Durbin Watson}

The Institutional investors and The external auditor have a significant relationship with STDF. The Institutional investor is statistically negatively correlated to STDF. These findings are supported by ( Hussainey,K. and Aljifri,k., 2012) as long as the number of institutional investors increase the firm will use less debt financing as there is a strategic alignment between the institutional investors and firm' managers. On the contrary, other studies debate that as long as the number of the institutional investors increase their voting rights will force managers to reduce their employment risk at the expenses of shareholders' benefits. These findings supported by (Shleifer, A. and Vishny, R., 1986).

The External auditor is statistically significant positively correlated with STDF. Firm engaged with one of the big four auditing firms will use more debt finance in capital structure. These findings are not supported by (Aljifri, 2008) and (Hussainey, 2009). (Lee et al., 2007) argue that this will decrease the information symmetry level between potential investors and managers. 
The size of the board of directors is statistically insignificant positively correlated with STDF. This findings is supported by (Jensen, 1986) and (Al-Najjar, B. and Hussainey, K., 2011a). Whereas , Berger et al., (1997) and Abor et al., (2005) argue that firm with the large board size members are more likely to utilize less debt financing since this put a pressure on managers to use less debt in order to improve the financial performance of the firm.

The Governmental ownership is statistically insignificant positively correlated with STDF indicating that firm with the higher proportion of governmental ownership will use the more STDF since funds will be secured from different source and government will monitor managers to work for the shareholder benefits. This finding is confirmed by (Gul, 1999).

The concentration of the Ownership is statistically insignificant positively correlated with STDF. Jensen et al., (1976) states that the higher the concentration of the ownership the higher the conflicts in agency issue because of the disagreement of benefits between contracting parties therefore, this leads to use more STDF and to provide positive signals to shareholders supporting the agency theory as supported by (Arun ,G.T. Haque,F. and Kirkpatrick, c., 2011).

For the control variables, the net profit is statistically insignificant negatively correlated with STDF. This finding is not supported by (Kayhan, A. and Titman, S., 2007). According to the pecking order hypothesis, profitable firms have a higher level of retained earnings to prefer internal finance rather than external finance.

The size of the firm is statistically insignificant positively correlated with STDF. Large firms use more short term debt finance as it is unlikely to go bankrupt due to the low of the default risk with contrast to small firms. This finding is supported by (Elsas, R. and Florysiak, D., 2008) and (Klapper, L. and Love, I., 2004). According to the Trade-off theory, large firms utilize more debt in its capital structure and these findings are supported through the statistical analysis outcomes.

The dividend Payout is statistically insignificant negatively correlated with STDF as supported by ( Aljifri,k. and Hussainey,K., 2012). The higher the dividend payout ratio the more control of management decisions over the free cash flows to decrease the use of STDF and use more retained earnings.

The coefficient of determination of the model is $\left(\mathrm{R}^{2}\right.$ ) is $56.2 \%$ (adjusted $\mathrm{R}^{2}$ is $55 \%$ ). $56 \%$ of The variance in short term debt finance is explained by independent and control variables whereas the remaining percentage $(44 \%)$ explained by other variables. The model is statistically significant. And there is no autocorrelation in the residuals as per Durbin Watson test outcome.

4.5.2 In terms of Long Term Debt Finance

LTDF $=\beta 0+\beta 1$ INSit $+\beta 2$ BSIZEit $+\beta 3$ EXTAUit $+\beta 4$ GOit $+\beta 5$ OWNit $+\beta 6$ PROit $+\beta 7$ FSIZit $+\beta 8$ DIVit $+\dot{\varepsilon}$.

Table 5. Panel Data Regression Model

\begin{tabular}{llll}
\hline Description & $\begin{array}{l}\text { Expected significant } \\
\text { based on hypothesis }\end{array}$ & Coefficient $\beta$ & (P-value) \\
\hline Constant & $-\mathrm{ve}$ & 0.097 & Significant \\
Board Size & $+\mathrm{ve}$ & -0.00536 & Not Significant \\
Institutional Investor & $+\mathrm{ve}$ & 0.00867 & Not Significant \\
Govern. Ownership & $+\mathrm{ve}$ & -0.00391 & Not significant \\
External Auditor & $+\mathrm{ve}$ & 0.02748 & Significant \\
Dummy variable & & & \\
Ownership concentration & $+\mathrm{ve}$ & -0.004572 & Significant \\
Net Profit & $-\mathrm{ve}$ & -0.002219 & Significant \\
Firm Size & $+\mathrm{ve}$ & -0.001162 & Significant \\
Dividend pay-out & $-\mathrm{ve}$ & 0.00241 & Not Significant \\
$\mathrm{R}^{2}$ & Adjusted $\mathrm{R}^{2}$ & F-Test & SE $* \mathrm{D} . \mathrm{W}$. \\
$67 \%$ & & Significant $92 \%$ & $0.122 \quad 2.52$ \\
\hline
\end{tabular}


The External auditor is statistically significant positively correlated with LTDF. This finding is supported due to the STDF regression outcomes. The efficiency of the external auditor is characterized as a way for information symmetry (the signal theory). Firm engaged with one the big four auditing firms will use more long term debt finance. These findings supported by (Aljifri, 2008), (Hussainey, 2009).

The concentration of the ownership is statistically significant negatively correlated with LTDF. The increase of the concentration of the ownership will push managers to disclose less information as potential investors can access internal information and monitoring managers' action resulting to use less long term debt finance. (Jensen et al., 1976) and (Arun ,G.T. Haque,F. and Kirkpatrick, c., 2011) state that the higher the concentration in the ownership will lead to the higher increase in the agency conflicts due to disagreement of interests between shareholders and managers and to use more short term debt finance as discussed previously.

The size of the Board of directors is statistically insignificant negatively correlated with LTDF. Firms with the larger board of directors are likely to use more debt. On the contrary, Berger et al, (1997) and Abor et al, (2005) supported the idea that firms with the large board of directors are likely to use less debt.

The governmental ownership is statistically insignificant negatively correlated with LTDF. Firms with the large proportion of the governmental ownership use less LTD as concluded by (Gul, 1999) and discussed before in the first model.

The Institutional investor is statistically insignificant positively correlated with LTDF.

For the control variables, The net profit is statistically significant negatively correlated with LTDF as supported by (Kayhan, A. and Titman, S., 2007).

The size of the firm is statistically significant negatively correlated with LTDF. Firms use short term finance due to economies of large scale as supported by ( Aljifri,k. and Hussainey,K., 2012).

The dividend Pay-out ratio is statistically insignificant positively correlated with LTDF as supported by ( Aljifri,k. and Hussainey,K., 2012).

The coefficient of determination of the model $\left(\mathrm{R}^{2}\right)$ is $67 \%$ (adjusted $\mathrm{R}^{2}$ is $64 \%$ ). $67 \%$ of the variance of short term debt finance can be explained by independent and control variables while the remaining percentage $(33 \%)$ explained by other factors. The model is statistically significant and there is no autocorrelation in the residuals according to Durbin Watson test.

\subsubsection{In terms of total debt Finance}

$\mathrm{TDF}=\beta 0+\beta 1 \mathrm{INSit}+\beta 2 \mathrm{BSIZEit}+\beta 3 \mathrm{EXTAUit}+\beta 4 \mathrm{GOit}+\beta 5$ OWNit $+\beta 6 \mathrm{PROit}+\beta 7 \mathrm{FSIZit}+\beta 8 \mathrm{DIVit}+\dot{\varepsilon}$.

Table 6. Panel Data Regression Model

\begin{tabular}{|c|c|c|c|c|}
\hline Description & $\begin{array}{l}\text { Expected significant } \\
\text { based on hypothesis }\end{array}$ & Coefficient $\beta$ & \multicolumn{2}{|c|}{ (P-value) } \\
\hline Constant & -ve & 0.15787 & \multicolumn{2}{|c|}{ Significant } \\
\hline Board Size & $+\mathrm{ve}$ & -0.00461 & \multicolumn{2}{|c|}{ Not Significant } \\
\hline Institutional Investor & $+\mathrm{ve}$ & -0.000867 & \multicolumn{2}{|c|}{ Not Significant } \\
\hline Govern. Ownership & $+\mathrm{ve}$ & 0.000105 & \multicolumn{2}{|c|}{ Not significant } \\
\hline External Auditor & $+\mathrm{ve}$ & 0.05884 & \multicolumn{2}{|c|}{ Significant } \\
\hline \multicolumn{5}{|l|}{ Dummy variable } \\
\hline Ownership concentration & $+\mathrm{ve}$ & -0.004068 & \multicolumn{2}{|c|}{ Not Significant } \\
\hline Net Profit & -ve & -0.001091 & \multicolumn{2}{|c|}{ Not Significant } \\
\hline Firm Size & $+\mathrm{ve}$ & -0.008658 & \multicolumn{2}{|c|}{ Significant } \\
\hline Dividend pay-out & -ve & -0.000351 & \multicolumn{2}{|c|}{ Not Significant } \\
\hline $\mathrm{R}^{2}$ & Adjusted $\mathrm{R}^{2}$ & F-Test & SE & $* \mathrm{D} . \mathrm{W}$ \\
\hline \multirow[t]{2}{*}{$60 \%$} & $57 \%$ & $\begin{array}{l}\text { Significant } \\
85 \%\end{array}$ & 0.132 & 2.72 \\
\hline & & p-value $<0.05$ & \\
\hline
\end{tabular}


The external auditor is statistically significant positively correlated with total debt finance. As supported by (Aljifri, 2008), (Hussainey, 2009) and Lee et al, (2007). The Institutional investor is statistically insignificant negatively correlated with total debt finance as supported by ( Aljifri,k. and Hussainey,K., 2012) and Pound, (1988). The increase the number of the institutional investors in the firm the lower the use of debt financing.

The size of the Board of directors is statistically insignificant negatively correlated with total debt finance. Firms with the higher size of the board use the less debt financing. However, The governmental ownership is statistically insignificant positively correlated with TDF meaning that the higher proportion of the governmental ownership the more uses of STDF.

The concentration of the ownership is statistically insignificant negatively correlated with total debt finance. The higher the concentration in the ownership the lower the use of debt finance in order to ensure a good information signal to the market to decrease the agency costs between contracting parties. On the contrary, Jensen et al, ( 1976) claimed that The higher the concentration in the ownership the higher agency conflicts which in turn resulted in the use of more debt financing to provide good signals to shareholders referring to agency theory.

In terms of The control variables, the size of the firm is statistically insignificant negatively correlated with TDF meaning that large firms use less debt finance. The net profit is statistically insignificant negatively correlated with TDF as supported by (Kayhan, A. and Titman, S., 2007). The dividend Pay-out is statistically insignificant negatively correlated with TDF as supported by (Aljifri,k. and Hussainey,K., 2012).

The coefficient of determination of the model $\left(\mathrm{R}^{2}\right)$ is $60 \%$ (adjusted $\mathrm{R}^{2}$ is $57 \%$ ). $67 \%$ of the variance of total debt finance can be explained by independent and control variables while the remaining percent which is $43 \%$ explained by other variables. The model is statistically significant.

4.5.4 Panel Least Square Regression Model :

Model before after conducting the Hausman test

\begin{tabular}{|c|c|c|c|c|c|c|}
\hline \multirow{3}{*}{ Models } & \multirow{2}{*}{\multicolumn{3}{|c|}{$\begin{array}{l}\text { Before Hausman test } \\
\text { Method: (Panel EGLS “general least square") }\end{array}$}} & \multicolumn{3}{|c|}{ After Hausman test } \\
\hline & & & & \multicolumn{2}{|c|}{$\begin{array}{l}\text { Method: (Panel EGLS } \\
\text { square") }\end{array}$} & \multirow{2}{*}{$\begin{array}{l}\text { “general least } \\
\text { TD }\end{array}$} \\
\hline & STF & LTF & $\mathrm{TD}$ & STF & LTF & \\
\hline $\begin{array}{l}\text { Significant } \\
\text { variables }\end{array}$ & $\begin{array}{l}\text { INST,EXTA } \\
\text { UD }\end{array}$ & $\begin{array}{l}\text { OWN, } \\
\text { PROFIT, } \\
\text { FSIZE,EXTA } \\
\text { UD, }\end{array}$ & $\begin{array}{l}\text { FSIZE, } \\
\text { EXTAUD, }\end{array}$ & $\begin{array}{l}\text { ROFIT,INS } \\
\mathrm{T}, \\
\text { EXTAUD, }\end{array}$ & $\begin{array}{l}\text { OWN,PRO } \\
\text { FI, FSIZE, }\end{array}$ & EXTAUD \\
\hline $\mathrm{R}^{2}$ & $54.5 \%$ & $65.6 \%$ & $59.3 \%$ & $70 \%$ & $76.4 \%$ & $70 \%$ \\
\hline $\begin{array}{l}\text { Adjusted } \\
\mathrm{R}^{2}\end{array}$ & $53.6 \%$ & $64.9 \%$ & $58.5 \%$ & $65.5 \%$ & $72.9 \%$ & $66.7 \%$ \\
\hline \multirow[t]{2}{*}{ SE } & 0.124 & 0.100 & 0.153 & 0.107 & 0.088 & 0.133 \\
\hline & 58.7 & 93.6 & 71.37 & 15.73 & 21.89 & 18.01 \\
\hline T-statistics & Significant & Significant & Significant & Significant & Significant & Significant \\
\hline Note & $\begin{array}{l}\text { STDF: short t } \\
\text { INST: institu } \\
\text { ownership cor }\end{array}$ & $\begin{array}{l}\text { m debt finance } \\
\text { onal investor; } \\
\text { entration; NPRC }\end{array}$ & $\begin{array}{l}\text { TDF: long te } \\
\text { XTAUD: ex } \\
\text { IT: net profit }\end{array}$ & $\begin{array}{l}\text { debt finance; } \\
\text { al auditor } \\
\text { SIZE: firm si }\end{array}$ & $\begin{array}{l}\text { CDF: total det } \\
\text { lummy varia } \\
\text { e; C: coeffici }\end{array}$ & $\begin{array}{l}\text { th finance } \\
\text { ble" ; OWN: } \\
\text { ent }\end{array}$ \\
\hline
\end{tabular}

Empirical results of the Hausman test proved that the cross sectional analysis is a random effect for the three models. The coefficients are significant before and after conducting the test except for the external auditor variable is insignificant in panel least square test in long term debt finance model.

In terms of short term debt finance. Results proved the profit variable is statistically insignificant in regression model but statistically significant in panel least square test.

In terms of the total debt finance. Results proved that the size of the firm is statistically insignificant in panel least square test. 
it is very obvious that after conducting the Hausman test $\mathrm{R}^{2}$ increases since the standard error decrease. This confirm the efficiency of the model after conducting the test.

\section{Conclusion}

The internal corporate governance variables are represented by the size of the board, the institutional investors, the concentration of the ownership and the governmental ownership. Whereas the external auditor is the external corporate governance variable.

The internal and external corporate governance variables have a statistical significant correlation with long term debt finance and short term debt finance before examining the Hausman test.

However, after examining the Hausman test, results proved that internal corporate governance variables only have a significant correlation with long term debt finance and short term debt finance.

The internal corporate governance variable represented only in the size of the board has a statistically significant correlation with total debt finance while it is excluded from Hausman test.

To compare with previous studies, the internal corporate governance variable represented in the institutional investors only has a statistically significant correlation with capital structure decisions in UAE firms (Hussainey, K. and Al-Najjar, B. , 2011b). The institutional investors has statistically insignificant correlation with short term debt finance indicating that Egyptian firms rely more on short term debt finance due to instability of economy growth resulting in the shortage of funds.

Sheikh and Wang (2012) found that the size of the board of directors, the managerial ownership and outside directors have a significant correlation with capital structure decisions. However compared to this study. We conclude that capital structure decisions under the Egyptian context is derived by both internal and external corporate governance variables. We find also that the differences of corporate governance frameworks that are constructed by legal, social and economic condition of each country play an important role in forming the effect of different corporate governance practices on capital structure decisions from one country to another.

\section{The Application of the Theories in Egypt Context}

Corporate governance variables are derived by three main independent variables (the institutional investors, the ownership concentration and the external auditor). Those variables found to have a statistical significant correlation with capital structure decisions. Trade-off theory found to not be applicable in Egypt. In terms of the signal and agency theory, there is a significant positive correlation with both the external auditor and the concentrate of the ownership with leverage ratio meaning that the monitor and control increase over internal finance decisions can be a positive signal to potential investors about the appreciation of firm value (Bokpin, 2010). The pecking order hypothesis is applied in the Egypt context since there is a significant negative relationship between the institutional investors and capital structure decisions meaning that firms with the large the institutional investors utilizing the higher debt in its capital structure. ( Aljifri,k. and Hussainey,K., 2012)

\section{References}

Abor, J. \& Biekpe, N. (2005). Does corporate governance affect the capital structure decision of Ghanaian SMEs? Bellville,Cape Town: University of Stellenbosch Business School.

Al-Najjar, B. \& Hussainey, K. (2011b). Revisiting the capital structure puzzle: UK evidence. Journal of Risk Finance, 12(4), 329-38. https://doi.org/10.1108/15265941111158505

Al-Najjar, B. \& Hussainey, K. (2011a). What drives firms' capital structure and dividend policy? working paper.

Al-Najjar, B. \& Taylor, P. (2008). The relationship between capital structure and ownership structure: evidence from Jordanian panel data. Managerial Finance, 34(12), 33-199. https://doi.org/10.1108/03074350810915851

Berger, P.G., Ofek, E. \& Yermack, D.L. (1997). Managerial entrenchment and capital structure decision. Journal of Finance, 52(4), 1411-38. https://doi.org/10.1111/j.1540-6261.1997.tb01115.x

Bharath, S., Pasquariello, P. \& Wu, G. (2009). Does asymmetric information drive capital structure decisions? Review of Financial Studies, 22(8), 3211-43. https://doi.org/10.1093/rfs/hhn076

Cadbury, A. (1992). Report of the committe on the Financial Aspects of Corporate Governance. london: Corporate Governance Committee of Financial Reporting Council, British stock Exchange and accountancy Profession.

Chang,Y.; Chou,R.; Huang,T. (2014). Corporate governance and the dynamics of capital structure: New evidence. Journal of Banking and Finance, 4, 374-385. https://doi.org/10.1016/j.jbankfin.2014.04.026 
Chang, R.P. \& Rhee, S.G. (1990). The impact of personal taxes on corporate dividend policy and capital structure decisions. Financial Management, 19(2), 21-31. https://doi.org/10.2307/3665631

Choudhury,T.,Mukherjee,K. \& Singh,V. (2001). Emerging Issues in Corporate Governance. Retrieved from http://www.scribd.com/doc/38647473/Emerging-Isuues-in-CG.

Crutchely,C.,Jensen,M.,Jahera,J. \& Raymond,J. (1999). Simultaneity of Financial decision making: The role of insitutional ownership. International review of Financial analysis, 8(2), 177-197. https://doi.org/10.1016/S1057-5219(99)00011-3

Demsetz, H., Villalonga, B.. (2001). Ownership structure and corporate performance. Journal of Corporate Finance, 7(3), 209-233. https://doi.org/10.1016/S0929-1199(01)00020-7

Donaldson,L. \& Davis,J. (1991). Stewardship Theory or Agency Theory:CEO Governance and Shareholder returns. Australian Journal of Management, 16(1), 49-61. https://doi.org/10.1177/031289629101600103

Eng, L.L. \& Mak,Y.T. (2003). Corporate governance and voluntary disclosure. Journal of accounting and public policy, 22, 325-45. https://doi.org/10.1016/S0278-4254(03)00037-1

Fauziah,W.;Yusoff,W. \& Alhaji,I. (2012). Insight of Corporate governance theories. Journal of Business and Management.

Fosberg, R. (2004). Agency problems and debt financing: leadership structure effects. Corporate governance, 4(1), 31-8. https://doi.org/10.1108/14720700410521943

Freeman, R. E. (1994, october). The Poltics of Stakeholder Theory: Some Future Directions. Business Ethics Quartely, 4(4). ISSN 1052-150X. 0409-042).

Ghazali, N.A.M \& Weetman. (2006). Perpetuating traditional influences; voluntary disclosure in Malaysia following economic crisis. Journal of international auditing and taxation, 15, 226-48.

Graham, J. \& Harvey, C. (2001). The theory and practice of corporate finance: evidence from the field. Journal of Financial Economics, 60, 187-243. https://doi.org/10.1016/S0304-405X(01)00044-7

Granado, P., Noelia.; Lopez, G., \& Jose. (2017). Corporate Governance and Capital Structure: A Spanish Study. European Management Review, 14(1), 33-45. https://doi.org/10.1111/emre.12088

Htay,S.,Salman,S. \& Meera,A. (2013, August). Let's Move to "Universal Corporate Governance Theory. Journal of Internet Banking and Commerce, 18(2).

Hussainey,K. \& Aljifri,k. (2012). Corporate governance mechanisms and capital structure in UAE. Journal of Applied Accounting Research,, 13(2), 145 - 160. https://doi.org/10.1108/09675421211254849

Haque,F.;Arun,G.T. \& Kirkpatrick,C. (2011). Corporate governance and capital structure in developing countries: a case study of Bangladesh. Applied Economics, (3), 673-681. https://doi.org/10.1080/00036840802599909

Javeed,A.; Hassan,M. \& Azeem,M. (2014). Interrelationship among Capital Structure, Corporate Governance Measures and Firm Value:Panel Study from Pakistan. Pakistan Journal of Commerce and Social Sciences, 8(3), p.572-589.

Jensen, M. C. (1986, May). Agency costs of free cash flow, corporate finance, and takeovers. American economic review, 76(2), 323-9.

Jensen,M. \& Meckling,W. (1976). Theory of the firm,managerial behavior, agency costsand ownership structure. journal of financial Economics, 3, 305_60. https://doi.org/10.1016/0304-405X(76)90026-X

Kayhan, A. \& Titman, S. (2007). Firms' histories and their capital structures. journal of Financial Economics, 83(1), 1-32. https://doi.org/10.1016/j.jfineco.2005.10.007

Klapper, L. \& Love, I. (2004). Corporate governance, investor protection and performance in emerging market. Journal of Corporate Finance, 10(5), 1-26. https://doi.org/10.1016/S0929-1199(03)00046-4

Kochhar, R. (1996). Explaining firm capital structure: the role of agency theory vs transaction cost economies. $\begin{array}{llll}\text { Strategic Management } & \text { Journal, } & \text { 713-28. }\end{array}$ https://doi.org/10.1002/(SICI)1097-0266(199611)17:9<713::AID-SMJ844>3.0.CO;2-9

La Porta, R., Lopez-de-Silanes, R. F., Shleifer, A., \& Vishny, R. W. (1997). Legal determinants of external finance. Journal of Finance, 52(3), 1131-1150. https://doi.org/10.3386/w5879 
Lakshmi, K. (2009). Ownership structure and capital structure: evidence from Indian firms. working paper. https://doi.org/10.2139/ssrn.1344113

Li-Kai, Loai., Taurn, Mukherjee., \& Wei, Wang., (2015). Corporate Governance and capital structure dymanics: An empirical study. The Journal of Financial Research, XXXVIII(2), 69-191.

Mehran, H. (1992). Executive incentive plans, corporate control, and capital structure. The Journal of Financial and Quantitative Analysis, 27(4), 539-60. https://doi.org/10.2307/2331139

Modigliani,F. \& Miller,M. (1958). The cost of capital,corporate finance and the theory of investment. American Economic Review, 53, 443_53.

Modigliani, F \& Miller, M. (1963). Corporate income taxes and the cost of capital: a correction. American Economic Review, 53(3), 433-43.

Myers, S. (1984). The capital structure puzzle. Journal of Finance, 39(3), 575-92. https://doi.org/10.3386/w1393

Myers, S.C., \& Majluf, N. (1984). Corporate financing and investment decisions when firms have information thatinvestors do not have. Journal of Financial Economics, 13, 187-222. https://doi.org/10.1016/0304-405X(84)90023-0

Pratheepkanth, P. (2011). Capital structure and financial performance:Evidence from selected business companies in Colombo stock exchange Srilanka. Journal of Arts, Science and commerce, 2.

Rocca, M. L. (2007). The influence of corporate governance on the relation between capital structure and value. The international journal of business in society, 7(3), 312 - 325. https://doi.org/10.1108/14720700710756580

Ross, S. (1977). The determination of financial structure: the incentive signaling approach. Bell Journal of Economics, 8, 23-40. https://doi.org/10.2307/3003485

Salim, M., \& Yadav, R. (2012). Capital structure and firm performance: Evidence from Malaysian listed companies. Procedia-Social and Behavioral Sciences, 65, 156-166. https://doi.org/10.1016/j.sbspro.2012.11.105

Samaha,K.;Dahawy,K.;Hussainey,K. \& Stapleton,P. (2012). The extent of corporate governance disclosure and its determinants in a developing market: The case of Egypt. Advances in Accounting, incorporating Advances in International Accounting. https://doi.org/10.1016/j.adiac.2011.12.001

Sheikh, N. \& Khan, Z. (2013). The impact of internal attributes of corporate governance on firm. International Journal of Commerce and Management, 23(1), 38-55. https://doi.org/10.1108/10569211311301420

Vivek, Mande,Young, K. Park., \& Mynugsoo, Son. (2012). Equity or Debt Financing: Does Good corporate governance matter? Corporate Governance: An International Review, 20(2), 195-211.

Vogt., Mara; Simao K., Itzhak D., Degenhart., \& Larissa; et al. (2017). The effect of Corporate governance in capital structure: an analysis in Brazilian belonging to index BM \& FBOVESPA consumption. Revista Ambiente Contabil, 9(1), 204-222.

Wen, Y., Rwegasira, K. \& Bilderbeek, J. (2002). Corporate governance and capital structure decisions of the Chinese listed firms. Corporate Governance, 10(2), 75-38. https://doi.org/10.1111/1467-8683.00271

World Bank. (2004). Egypt corporate governance report: report on the observation of standards and codes (ROSC), corporate governance country assessment retrieved march 2015, http://www. Worldbank.org/ifa/rosc_cgegypt2.pdf.

Ya-kai, chang., Robin K. Chou. (2014). Corporate Governance and the dynamics of capital structure: new eveidence. Journal of Banking and Finance, 48, 374.385. 


\section{$\underline{\text { Appendix }}$}

The Study Sample (EGX 100 Index Constituents)

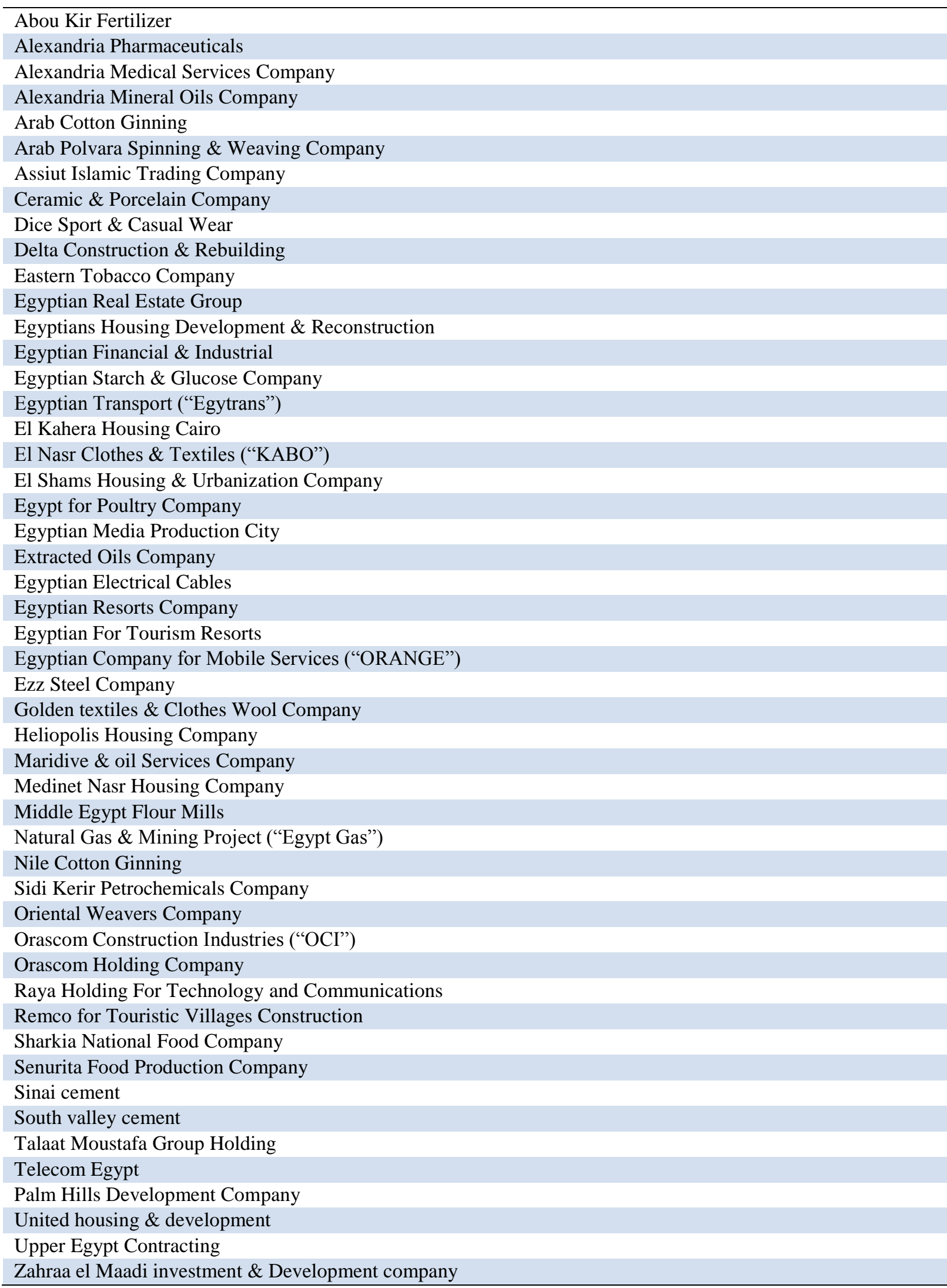

